\title{
Powdery mildew of ornamental species caused by Oidiopsis haplophylli in Brazil
}

\author{
Ailton Reis ${ }^{1,3}$; Leonardo Silva Boiteux ${ }^{1,3} \&$ Milton Luiz Paz-Lima ${ }^{2}$
}

${ }^{1}$ Embrapa Hortaliças, Centro Nacional de Pesquisa de Hortaliças (CNPH), CP 218, 70359-970, Brasília-DF; ${ }^{2}$ Universidade de Brasília, Campus Darcy Ribeiro, Departamento de Fitopatologia, CP 4457, 70910-900, Brasília-DF, Brazil; ${ }^{3}$ CNPq (MCT) Fellowship. E-mail: ailton@cnph.embrapa.br

Data da chegada: 18/01/2006. Aceito para publicação em: 17/04/2007.

\section{ABSTRACT}

Reis, A.; Boiteux, L. S. \& Paz-Lima, M. L. Powdery mildew of ornamental species caused by Oidiopsis haplophylli in Brazil. Summa Phytopathologica, v.33, n.4, p.405-408, 2007.

Oidiopsis haplophylli (syn. Oidiopsis sicula) was identified as the causal agent of powdery mildew diseases occurring on five ornamental species in Brazil. This disease was observed in plastic house-grown lisianthus (Eustoma grandiflorum: Gentianaceae), in nasturtium (Tropaeolum majus: Tropaeolaceae) cultivated under open field conditions and in greenhouse-grown calla lily (Zantedeschia aethiopica: Araceae), impatiens (Impatiens balsamina: Balsaminaceae) and balloon plant (Asclepias physocarpa: Asclepiadaceae). Typical disease symptoms consisted of chlorotic areas on the upper leaf surface corresponding to a fungal colony in the abaxial surface. With the disease progression, these chlorotic areas eventually turned to necrotic (brown) lesions. Fungi morphology on all hosts was similar to that described for the imperfect stage of
Leveillula taurica (O. haplophylli). The Koch's postulates were fulfilled by inoculating symptom-free plants via leaf-to-leaf contact with fungal colonies. Additional inoculations using an isolate of $O$. haplophylli from sweet pepper (Capsicum annuum) demonstrated that it is pathogenic to all five species belonging to distinct botanical families, indicating lack of host specialization. This is the first formal report of a powdery mildew disease on lisianthus, calla lilly, impatiens and nasturtium in Brazil. It is, to our knowledge, the first report of $O$. haplophyllii infecting A. physocarpa, extending the host range of this atypical powdery mildew-inducing fungus. This disease might become important on these ornamental crops especially in protected cultivation and also under field conditions in hot and dry areas of Brazil.

Additional Keywords: etiology, Leveillula taurica, lisianthus, calla lily, nasturtium, impatiens, Asclepias physocarpa.

\section{RESUMO}

Reis, A.; Boiteux, L. S. \& Paz-Lima, M. L. Oídio em plantas ornamentais, causado por Oidiopsis haplophylli, no Brasil. Summa Phytopathologica, v.33, n.4, p.405-408, 2007.

O fungo Oidiopsis haplophylli (= O. sicula) foi identificado como sendo o agente causal de uma nova doença do tipo oídio em beijo-defrade (Impatiens balsamina: Balsaminaceae), capuchinha (Tropaeolum majus: Tropaeolaceae), copo-de-leite (Zantedeschia aethiopica: Araceae), lisianthus (Eustoma grandiflorum: Gentianaceae) e florborboleta (Asclepias physocarpa: Asclepiadaceae) em Brasília-DF, Brasil. Esta doença foi observada em condições de casa de vegetação em beijo-de-frade, copo-de-leite, lisianthus e flor-borboleta e em condições de campo na capuchinha. O sintoma típico é o aparecimento de uma área clorótica na superfície superior da lâmina foliar que corresponde a uma colônia fúngica na superfície inferior. Com o progresso da doença, estas lesões tornavam-se necróticas e eventualmente coalesciam. As características morfológicas, observadas em microscopia de luz, corresponderam àquelas descritas para a fase imperfeita do fungo Leveillula taurica (O. haplophylli). Os testes de patogenicidade foram completados via inoculação por contato entre folhas sadias e folhas apresentado colônias do fungo. Um isolado de pimentão foi também patogênico a estas cinco espécies ornamentais (pertencentes a diferentes famílias botânicas) confirmando a ausência de especialização por hospedeiro deste fungo. Este é o primeiro registro deste patógeno nestas espécies ornamentais no Brasil e, provavelmente, o primeiro relato de flor-borboleta como hospedeira. Este oídio pode se tornar importante para o cultivo destas espécies em cultivo protegido ou condições de clima quente e seco.

Palavras-chave adicionais: etiologia, Leveillula taurica, lisianthus, copo-de-leite, capuchinha, impatiens, Asclepias physocarpa.

Ornamental pot plants and flowers (for both exporting and internal markets) are among the fastest growing agribusiness segments in Brazil. In the first half of 2005, total exports of this sector reached US\$ 14 millions with an expansion of $19.5 \%$ compared to the same period of the year 2004. In Brazil, due to the large number of microclimate conditions, many ornamental plant species can be cultivated throughout the year. In addition, many ornamental plants are now being cultivated under greenhouse and plastic house. Cultivation under open field conditions using drip- irrigation is also increasing in the Northeast and Central Brazil, especially during the hot, dry season. In these circumstances, plant pathogens that are dependent upon high humidity and free water for infection and/or dissemination become minor problems. On the other hand, this novel cultivation system has favored a whole new set of pathogens that were not formerly reported as major diseases in the country. One group of pathogens that became prevalent under these conditions comprises fungi belonging to the Erysiphaceae, which are able to induce powdery mildew diseases 

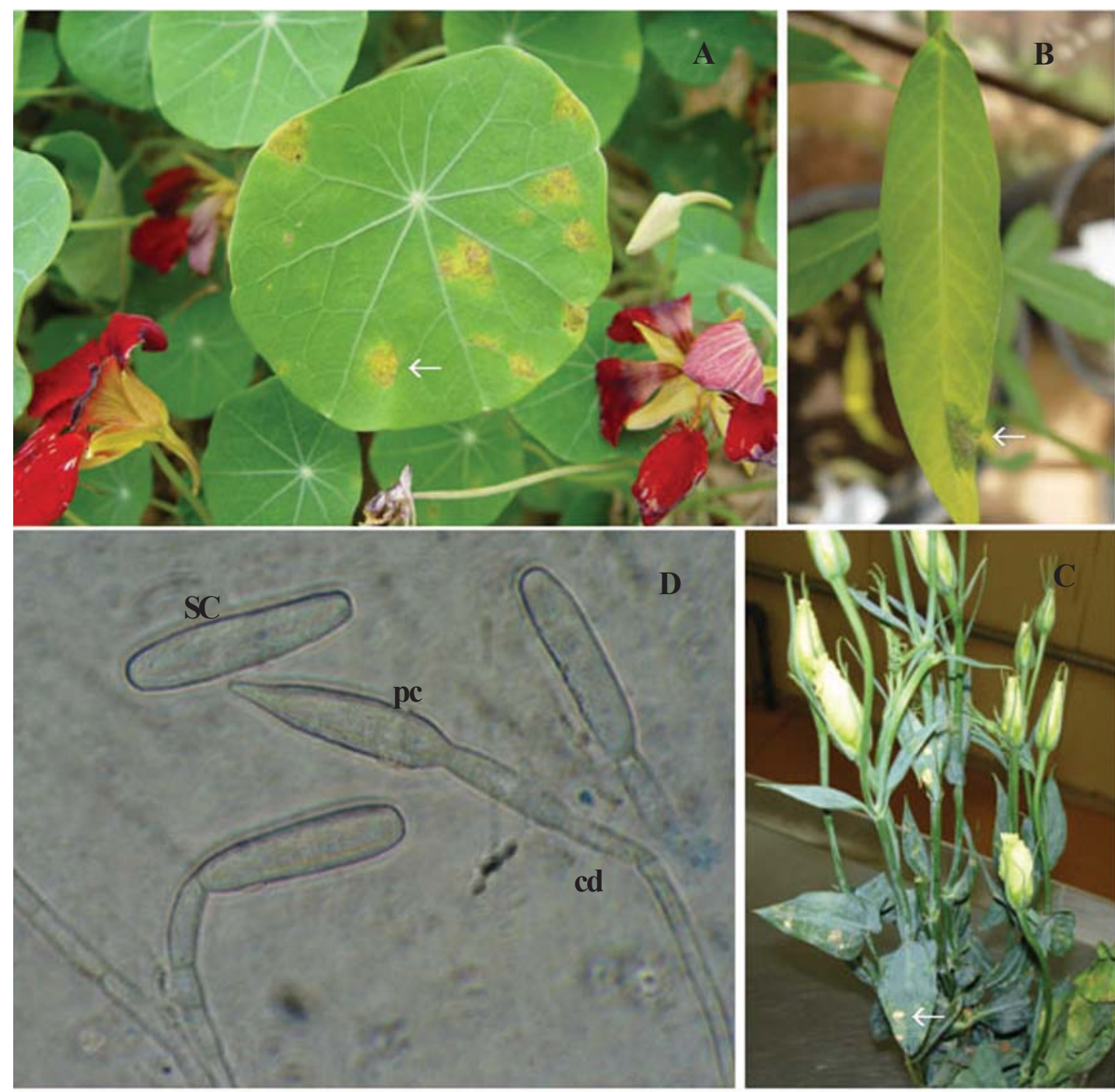

Figure 1. Symptoms of powdery mildew, caused by Oidiopsis haplophylli, in ornamental species: $\mathrm{A}=$ nasturtium, $\mathrm{B}=$ balloon plant, $\mathrm{C}=$ lisianthus and $\mathrm{D}$ $=$ structures of the imperfect state of $O$. haplophylli $(\mathrm{pc}=$ primary conidium, $\mathrm{sc}=$ secondary conidium and $\mathrm{cd}=$ conidiophores). Arrows are indicating necrotic lesions induced by the fungus.

in many plant species. Oidiopsis haplophylli Rulamort (= Oidiopsis sicula Scalia or Oidiopsis taurica Salmon) is one of the most economically important fungal species reported infecting a wide range of vegetables and ornamental plants throughout the world $(4,9)$. In Brazil, powdery mildew outbreaks caused by $O$. haplophylli have been reported on processing tomatoes, freshmarket tomatoes and sweet peppers in several Brazilian States $(3,8,11,12,13)$. The host range of $O$. haplophylli is expanding in the country with several new reports on distinct vegetable and ornamental hosts $(10,11,13)$. Oidiopsis haplophylli has not been reported as seed-transmissible, therefore, it is more likely that this fungus was introduced in Brazil via infected ornamental pot plants (11).

In recent years, novel powdery mildew diseases have been observed affecting a range of ornamental species in distinct growing regions in Brasília (Federal District, Brazil). Powdery mildew diseases were noticed on impatiens or touch-me-not (Impatiens balsamina L.: Balsaminaceae), balloonplant [Asclepias physocarpa (E. Mey.) Schlechter: Asclepiadaceae] and white arum lily or calla lily [Zantedeschia aethiopica (L.) Spreng.: Araceae] cultivated under glasshouse conditions. Plastic house Lisianthus [Eustoma grandiflorum (Raf.) (Shinners): Gentianaceae] in São Sebastião (Federal District) and open field-grown nasturtium (Tropaeolum majus L.: Tropaeolaceae) in Ponte Alta (Federal District) were also found to be affected by a new powdery mildew disease. In the present work, we report that all diseases were caused by a single agent, O. haplophylli.

Leaf samples of impatiens, balloon plant and calla lily collected in a glasshouse in Brasília (Federal District) showed disease symptoms characterized by yellow spots on upper surface of leaves corresponding to the establishment of a fungal colony in the abaxial surface. As disease progressed the yellow spots developed a light brown color. Similar symptoms were also observed in leaf samples of field-grown nasturtium in Gama (Federal District). Lisianthus plants collected in São Sebastião (Federal District) displayed similar symptoms (Figure 1A-C).

The affected areas were visualized under stereomicroscope, symptomatic leaf sections were removed and the fungal structures were visualized in microscope slides prepared by mounting thin host tissue slices in lactophenol. Measurements of length and width were done using 50 primary and 50 secondary conidia that were collected from each host described in the present investigation. Other morphological aspects of the fungal structures associated with the imperfect stages of powdery mildew fungi $(2,4,9)$ were observed including color of conidia, vacuoles and type of germination tube. Pathogenicity tests were performed by inoculating symptom-free plants via leaf-to-leaf contact with fungal colonies. A group of test plants was separately inoculated with each of the 
Table 1. Length and diameter of primary and secondary conidia of Oidiopsis haplophylli obtained from impatiens (Impatiens balsamina: Balsaminaceae), nasturtium (Tropaeolum majus: Tropaeolaceae) calla lily (Zantedeschia aethiopica: Araceae), lisianthus (Eustoma grandiflorum: Gentianaceae), balloonplant (Asclepias physocarpa: Asclepiadaceae), and sweet pepper (Capsicum annuum).

\begin{tabular}{|c|c|c|c|c|}
\hline \multirow[b]{2}{*}{ Host } & \multicolumn{2}{|c|}{ Primary Conidia ${ }^{*}$} & \multicolumn{2}{|c|}{ Secondary conidia ${ }^{*}$} \\
\hline & Range & Average & Range & Average \\
\hline Impatiens & $57.6-68.2 \times 16.3-21.1$ & $62.8 \times 19.0$ & $52.8-70.1 \times 11.5-21.1$ & $59.6 \times 17.1$ \\
\hline Nasturtium & $49.0-71.0 \times 15.0-18.0$ & $60.0 \times 16.5$ & $44.0-64.0 \times 11.0-23.0$ & $56.6 \times 16.2$ \\
\hline Calla lily & $51.7-73,2 \times 14.2-18.9$ & $58.5 \times 15.4$ & $55.3-69.0 \times 15.6-17.9$ & $56.8 \times 15.4$ \\
\hline Lisianthus & $54.2-71.4 \times 13,6-18.5$ & $60.1 \times 15.7$ & $54.5-70.6 \times 13.8-18.7$ & $58.9 \times 15.2$ \\
\hline Balloon plant & $51.2-71.1 \times 14.3-18.3$ & $58.2 \times 15.3$ & $56.0-68.8 \times 14.7-17.8$ & $56.5 \times 14.8$ \\
\hline Sweet pepper ${ }^{* *}$ & $59.6-74.4 \times 14.3-19.1$ & $62.4 \times 15.2$ & $57.2-71.1 \times 13.7-18.9$ & $62.1 \times 14.9$ \\
\hline
\end{tabular}

* Length and diameter, measured in $\mu \mathrm{m}$.

Standard host plant.

five isolates obtained from each host and also with one isolate from pepper.

Observations on the light microscope revealed that mycelium is predominantly endophytic with the presence of conidiophores emerging through leaf stomata. Some conidiophores were divided into two to three branches. Ellipsoidal, light pale conidiospores (conidia) were borne predominantly single and terminally on the conidiogenic cell. The main light microscopy and host range diagnostic characters of $O$. haplophylli were in complete agreement with that described by Braun (4) and Palti (9): large primary conidia with lanceolate shape and secondary conidia with a cylindrical shape (Figure 1D), presence of endophytic mycelicum and notlobed appressorium. The presence of the sexual stage (Leveillula taurica) was not observed in the leaf samples of any host plant throughout this investigation.

The length and diameter measurements taken from primary and secondary conidia of the impatiens, balloon plant, calla lily and nasturtium isolates as well as the standard $O$. haplophylli isolate from sweet pepper (Capsicum annuum L.) cv. Ikeda are shown in Table 1. All morphometrical characteristics (including their ranges) are in agreement with the ones reported in the literature for $O$. haplophylli $(2,4,9)$.

Koch's postulates were fulfilled for all five ornamental species. The host range studies indicated that $O$. haplophylli isolate from sweet pepper is also virulent on these five ornamental plants, belonging to five distinct botanical families. Therefore, there was no clear indication of host specialization of these isolates. This suggests that sweet pepper could be a potential source of inoculum of $O$. haplophylli once there is a large amount of fields of this vegetable crop in Federal District area. Furthermore, plants of impatiens, balloon plant and calla lily, infected by this fungus were initially collected in a glasshouse with sweet pepper plants presenting powdery mildew symptoms. This promiscuous host range clearly indicates that these ornamental plant species might serve as alternative hosts of both tomato and sweet pepper powdery mildews.

Severe outbreaks of powdery mildew on sweet pepper and tomato caused by $O$. haplophylli were initially restricted to plastic house conditions in Brazil. This powdery mildew disease is now economically important for tomato and sweet pepper under both plastic house and open-field conditions $(8,11,13)$. This is the first formal report of a powdery mildew disease on lisianthus, greenhouse calla lilly, I. balsamina, A. physocarpa and nasturtium in Brazil. Powdery mildew caused by $O$. haplophylli was already reported elsewhere for lisianthus $(5,6)$, greenhouse calla lily $(7$,
14), I. balsamina (9) and nasturtium (1). However, to our knowledge, it is the first report of $O$. haplophyllii infecting $A$. physocarpa, extending the host range of this powdery mildewinducing fungus. These hosts belong to five botanical families, which is in agreement with the current notion that $O$. haplophylli is an atypical powdery mildew since it has a wide host range usually not observed for obligate parasites of the Erysiphaceae family (4, $9,10,11)$.

These powdery mildew diseases might become important on these ornamental crops especially in protected cultivation and under field conditions in hot and dry areas such as those in the Central and Northeast regions of Brazil. The wide host range of O. haplophylli could have important epidemiological implications when establishing disease control strategies for these ornamental crops.

\section{LITERATURE CITED}

1. Besri, M.; Hormattallah, A. Manifestation et mode de conservation de Leveillula taurica, agent de l'oidium de la tomate au Maroc. Phytopathologische Zeitschrift, Berlin, v.112, n.4, p.348$354,1985$.

2. Boesewinkel, H.J. The morphology of the imperfect states of powdery mildews (Erysiphaceae). The Botanical Review, New York, v. 46, p.167-224, 1980

3. Boiteux, L.S.; Santos, J.R.M.; Lopes, C.A. First record of powdery mildew of sweet-pepper (Capsicum annuum) incited by Leveillula taurica in Brazil. Fitopatologia Brasileira, Brasília, v.19, supl., p.304, 1994.

4. Braun, U. A monograph of the Erysiphales (powdery mildews). Nova Hedwigia, Stuttgart, v.89, p.1-700, 1987.

5. Garibaldi, A.; Rapetti, S.; Aloi, C.; Gullino, M.L.; Bozzano, G. Malattie delle piante da fiore ornamentali recentemente osservate in Italia. Informatore Fitopatologico, Turim, v.40, n.5, p.915,1990

6. Koike, S.T.; Tjosvold, A.S.; Greene, I.D. Powdery mildew of Eustoma caused by Leveillula taurica in California. Plant Disease, St. Paul, v.79, n.4, p.426, 1995.

7. Koike, S.T.; Beckman, P. Characterization of powdery mildew caused by Leveillula taurica on calla lily in California. Plant Disease, St. Paul, v.86, n.2, p.187, 2002.

8. Mendes, M.A.S.; Silva, V.L.; Dianese, J.C.; Ferreira, M.A.S.V.; Santos, C.E.N.; Gomes Neto, E.; Urben, A.F.; Castro, C. Fungos em Plantas no Brasil. Brasília; Embrapa, 1998. 555p.

9. Palti, J. The Leveillula Mildews. The Botanical Review, New York, v. 54, n.4, p.423-535, 1988.

10. Reis, A., Boiteux, L.S., Paz-Lima, M.L., Silva, P.P., Lopes, C.A. Powdery mildew of Allium species caused by Oidiopsis taurica in Brazil. Horticultura Brasileira, Brasília, v.22, n.4, p.758-760, 2004.

11. Reis, A.; Boiteux, L.S.; Henz, G.P.; Lopes, C.A. Oidiopsis haplophylli (Leveillula taurica): um patógeno polífago e amplamente 
distribuído no Brasil. Comunicado Técnico, Embrapa Hortaliças, Brasília, n. 26, 2005. 13p.

12. Santos, J.R.M.; Boiteux L.S. Ocorrência de oídio (Leveillula taurica e Erysiphe cichoracearum) em tomateiro no Distrito Federal. Fitopatologia Brasileira, Brasília, v.19, supl., p.313, 1994.

13. Souza, V.L.; Café Filho, A.C. Resistance to Leveillula taurica in the genus Capsicum. Plant Pathology, London, v.52. p.613$619,2003$.

14. YuhKun, C., ChingChung, C. LungChung, C. Occurrence of powdery mildew on golden calla lily in Taiwan. Annals of the Phytopathological Society of Japan, Tokyo, v.62, n.6, p.580-583, 1996. 